\title{
Radix clematidis extract protects against cytokine- and streptozotocin-induced $B$-cell damage by suppressing the NF-kB pathway
}

\author{
EUN-KYUNG KIM ${ }^{1 *}$, MI-YOUNG SONG ${ }^{1 *}$, TAE-OK HWANG ${ }^{3}$, HEE JIN KIM $^{2}$, \\ WOO SUNG MOON ${ }^{2}$, DO-GON RYU ${ }^{3}$, HONG-SEOB SO ${ }^{4}$, RAEKIL PARK ${ }^{4}$, \\ JIN-WOO PARK ${ }^{1}$, KANG-BEOM KWON ${ }^{3}$ and BYUNG-HYUN PARK ${ }^{1}$
}

\begin{abstract}
Departments of ${ }^{1}$ Biochemistry and ${ }^{2}$ Pathology, Medical School and Institute for Medical Sciences, Chonbuk National University, Jeonju, Jeonbuk 561-756; ${ }^{3}$ Department of Physiology, School of Oriental Medicine, Wonkwang University;

${ }^{4}$ Vestibulocochlear System Research Center and Department of Microbiology, College of Medicine,

Wonkwang University, Iksan, Jeonbuk 570-749, Korea
\end{abstract}

Received April 29, 2008; Accepted June 2, 2008

DOI: 10.3892/ijmm_00000029

\begin{abstract}
Although Radix clematidis has commonly been used in Chinese medicine for the treatment of arthralgia, the anti-diabetic effects of Radix clematidis have not yet been reported. In the present study, we demonstrated that Radix clematidis extract (RCE) could prevent cytokine-induced ß-cell damage and streptozotocin (STZ)-induced diabetes in mice. Treatment of RINm5F insulinoma cells with interleukin-1 $1 \beta$ and interferon- $\gamma$ reduced cell viability; however, RCE protected the cells from this cytokine-mediated viability reduction in a concentration-dependent manner. Additionally, incubation with RCE resulted in a significant suppression of cytokine-induced nitric oxide (NO) production, which was correlated with reduced levels of the inducible form of NO synthase (iNOS) mRNA and protein. The molecular mechanism by which RCE inhibited iNOS gene expression appeared to involve inhibition of $\mathrm{NF}-\kappa \mathrm{B}$ activation. Furthermore, RCE abolished the cytokine-induced increases in $\mathrm{NF}-\kappa \mathrm{B}$ binding activity and p65 subunit levels in the nucleus, as well as $\mathrm{I} \kappa \mathrm{B} \alpha$ degradation in the cytosol when compared to
\end{abstract}

Correspondence to: Dr Byung-Hyun Park, Department of Biochemistry, Medical School and Institute for Medical Sciences, Chonbuk National University, Jeonju, Jeonbuk 561-756, Korea

E-mail: bhpark@chonbuk.ac.kr

Dr Kang-Beom Kwon, Department of Physiology, School of Oriental Medicine, Wonkwang University, Iksan, Jeonbuk 570-749, Korea

E-mail: desson@wonkwang.ac.kr

${ }^{*}$ Contributed equally

Key words: Radix clematidis, 3 cells, cytokine, streptozotocin, $\mathrm{NF}-\mathrm{\kappa B}$, nitric oxide unstimulated cells. The protective effect of RCE was further demonstrated by the observed suppression of NF-кB-dependent iNOS expression and normal insulin secreting responses to glucose in cytokines-treated islets. The anti-diabetic effect of RCE was even more striking in vivo, where nearly complete protection against STZ-induced diabetes was observed. Treatment of mice with STZ resulted in hyperglycemia and hypoinsulinemia, which was further evidenced by immunohistochemical staining; however, pretreatment of mice with RCE blocked the destruction of STZ-induced islets and the development of type 1 diabetes.

\section{Introduction}

Type 1 diabetes mellitus is an autoimmune disease that causes selective destruction of insulin producing $B$ cells in the Langerhans islets (1). During early stages of the disease, histological findings show features of insulitis, which is characterized by the infiltration of immune cells such as $\mathrm{T}$ lymphocytes, macrophages, and natural killer cells into the pancreatic islets $(2,3)$. These cells produce and release various cytokines that act as humoral mediators of the immunologic process. Therefore, cytokines such as interleukin-1ß (IL-1ß), tumor necrosis factor- $\alpha$, and interferon- $\gamma(\mathrm{IFN}-\gamma)$ have been implicated as key effector molecules in $\beta$-cell function and viability (4).

$\mathrm{IL}-1 \beta$ alone or in combination with tumor necrosis factor- $\alpha$ or IFN- $\gamma$ causes the production of excess nitric oxide (NO) in pancreatic islets $(5,6)$. NO is produced by the oxidation of L-arginine to L-citruline by nitric oxide synthase (NOS), and excess NO may inhibit mitochondrial metabolism, modify protein, and cleave DNA $(7,8)$. It has also been reported that streptozotocin (STZ), a commonly used diabetogenic agent, produces NO $(9,10)$. Several studies have been conducted to evaluate the possible role of NO in the pathogenesis of autoimmune diabetes, the results of which have demonstrated that nuclear factor $\kappa \mathrm{B}(\mathrm{NF}-\kappa \mathrm{B})$-dependent $\mathrm{NO}$ production plays a key role in the dysfunction and destruction of $\beta$ cells. 
The production of NO is regulated by transcription factors that bind to specific sites in the promoter of the inducible form of the NOS (iNOS) gene. Transcriptional NF- $\mathrm{B}$, which can be activated by cytokines and streptozotocin, has been implicated as a key signaling mediator of the induction of iNOS (11-13). NF-kB is initially located in the cytoplasm as

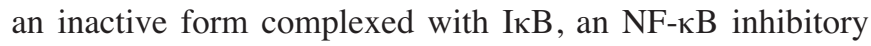
factor. However, various inducers cause this complex to dissociate, presumably via the phosphorylation of I $\mathrm{KB}$, thereby allowing $\mathrm{NF}-\kappa \mathrm{B}$ to be released from the complex. NF- $\mathrm{KB}$ then translocates to the nucleus, where it interacts with its DNA recognition sites to mediate gene transcription $(14,15)$.

Radix clematidis is the name given to the root of Clematis florida $T_{H U N B}$, a member of the Ranuncluaceae family. Radix clematidis is commonly used in traditional Chinese medicine to alleviate joint pain and relieving swelling. In the present study, we evaluated the preventive effects of Radix clematidis extract (RCE) on cytokine- and STZ-induced pancreatic Bcell damage both in vitro and in vivo. $\mathrm{RCE}$ was found to block the cytokine- and STZ-induced NF- $\mathrm{KB}$ pathway, thereby protecting the pancreatic $B$ cells. These results indicate that Radix clematidis may be useful as an anti-diabetic agent.

\section{Materials and methods}

Cell culture. RINm5F (RIN) cells were purchased from the American Type Culture Collection and grown at $37^{\circ} \mathrm{C}$ under a humidified, $5 \% \mathrm{CO}_{2}$ atmosphere in RPMI-1640 medium (HyClone, South Logan, UT) supplemented with $10 \%$ fetal bovine serum and $2 \mathrm{mM}$ glutamine, $100 \mathrm{U} / \mathrm{ml}$ of penicillin, $100 \mu \mathrm{g} / \mathrm{ml}$ of streptomycin, and $2.5 \mu \mathrm{g} / \mathrm{ml}$ of amphotericin B.

Preparation of Radix clematidis extract. Radix clematidis was purchased from Wonkwang Oriental Medical Hospital in Iksan, Jeonbuk, Korea and its identity was confirmed by HoJoon Song, keeper of the Herbarium. Voucher samples were preserved for reference in the Herbarium of the Department of Physiology, School of Oriental Medicine, Wonkwang University (Omcphy, 2005-58). Radix clematidis (200 g) was then ground and extracted in boiling water for $4 \mathrm{~h}$. The extract was centrifuged at 3,000 x $\mathrm{g}$ for $20 \mathrm{~min}$, after which the supernatant was concentrated to $200 \mathrm{ml}$ under reduced pressure and then freeze dried to $20.4 \mathrm{~g}$. The sterile extract was stored at $-70^{\circ} \mathrm{C}$ until use.

MTT assay for cell viability. The viability of cultured cells was determined by assaying the reduction of 3-(4,5-dimethylthiazol2-yl)-2,5-diphenyltetrazolium bromide (MTT) to formazan. Briefly, the cells were treated with cytokines for 24 or $48 \mathrm{~h}$, after which they were washed twice with PBS, and MTT (100 $\mu \mathrm{g} / 100 \mu \mathrm{l}$ of PBS) was added. The cells were incubated at $37^{\circ} \mathrm{C}$ for $1 \mathrm{~h}$, after which DMSO $(100 \mu \mathrm{l})$ was added to dissolve the formazan crystals. The absorbance was measured at $570 \mathrm{~nm}$ using a spectrophotometer.

5-Bromo-2-deoxyuridine (BrdU)-labeling cell proliferation assay. A cell proliferation enzyme-linked immunosorbant assay (BrdU kit; Amersham Biosciences, Piscataway, NJ) was used to measure the incorporation of BrdU during DNA synthesis following the manufacturer's protocols. Briefly, following treatment with cytokines for $24 \mathrm{~h}$ or $48 \mathrm{~h}, \mathrm{BrdU}$ $(10 \mu \mathrm{M})$ was added to the culture medium for $2 \mathrm{~h}$. The BrdUlabeled cells were fixed, after which the DNA was denatured in fixative solution for $30 \mathrm{~min}$ at room temperature. The cells were then incubated with peroxidase-conjugated anti-BrdU antibody for $2 \mathrm{~h}$ at room temperature, followed by washing three times with washing solution. The immune complex was detected by inducing a 3,3',5,5'-tetramethylbenzidine substrate reaction and measuring the absorbance at $405 \mathrm{~nm}$.

NO measurement. Biologically produced NO is rapidly oxidized to nitrite and nitrate in aqueous solutions (16). Therefore, NO production was evaluated by measuring the nitrite concentrations in the cell-free culture supernatant using a colorimetric assay. Following treatment with cytokines for $24 \mathrm{~h}, 100 \mu \mathrm{l}$ aliquots of the culture supernatants were incubated with $100 \mu 1$ of a modified Griess reagent $(1: 1$ mixture of $1 \%$ sulfanilamide in $30 \%$ acetic acid and $0.1 \%$ $\mathrm{N}$-(1-naphthyl) ethylenediamine dihydrochloride in $60 \%$ acetic acid) at room temperature for $5 \mathrm{~min}$. The absorbance at $540 \mathrm{~nm}$ was measured using a spectrophotometer. Next, the concentrations of NO were determined using a linear standard curve generated from serial dilutions of sodium nitrite in working medium.

RNA isolation and real-time PCR for iNOS. Total RNA was isolated from RIN cells or islets using TRIzol reagent (Invitrogen, Carlsbad, CA). Briefly, RNA was precipitated with isopropanol and dissolved in DEPC-treated distilled water. The total RNA ( $2 \mu \mathrm{g})$ was treated with RNase-free DNase (Invitrogen), and first-strand cDNA was generated using the random hexamer primer provided in the first-strand cDNA synthesis kit (Applied Biosystems, Foster City, CA). The specific primers for iNOS were designed using primer express software (Applied Biosynthesis): iNOS (accession no. NM_012611), 5'-TGTGCTAATGCGGAAGGTCAT-3' (forward), and 5'-CGACTTTCCTGTCTCAGTAGCAAA-3' (reverse). The sequence for the control 18S ribosomal RNA was purchased from Applied Biosystems and used as the invariant control. The real-time PCR reaction, which was contained in a final volume of $10 \mu \mathrm{l}$, consisted of $10 \mathrm{ng}$ of reverse transcribed total RNA, forward and reverse primers at a concentration of $167 \mathrm{nM}$ and 2X PCR master mixture. The PCR reaction was conducted in 384-well plates using the ABI PRISM 7900HT Sequence Detection System (Applied Biosystems). All reactions were conducted in triplicate.

Western blot analysis. Cells or islets were homogenized in $100 \mu 1$ of ice-cold lysis buffer (20 mM HEPES, pH 7.2, 1\% Triton X-100, 10\% glycerol, $1 \mathrm{mM}$ PMSF, $10 \mu \mathrm{g} / \mathrm{ml}$ leupeptin, and $10 \mu \mathrm{g} / \mathrm{ml}$ aprotinin). The homogenates, which contained $20 \mu \mathrm{g}$ of protein, were then separated by SDS-PAGE with $7.5 \%$ (for iNOS) or $12 \%$ resolving (for I $\mathrm{KB} \alpha, \mathrm{p} 65, \beta$-actin, and PCNA) and $3 \%$ acrylamide stacking gels, and then transferred to nitrocellulose sheets. Next, the nitrocellulose paper was blocked with $2 \%$ bovine serum albumin and then incubated for $4 \mathrm{~h}$ with $1 \mu \mathrm{g} / \mathrm{ml}$ of primary antibody (Santa Cruz Biochemicals, Santa Cruz, CA). Horseradish peroxidase-conjugated IgG (Zymed, South San Francisco, CA) was used as a secondary antibody. Protein expression 
levels were then determined by analyzing the signals captured on the nitrocellulose membranes using a Chemi-doc image analyzer (Bio-Rad, Hercules, CA).

Preparation of nuclear extracts. After treatment with cytokines or STZ, cells or pancreatic tissues were homogenized, washed twice with ice-cold PBS ( $\mathrm{pH} 7.9$ ), and pelleted at 12,000 x g for $30 \mathrm{sec}$. The pellet was suspended in cold hypotonic lysis buffer (10 mM HEPES, 1.5 mM MgCl $2,0.2 \mathrm{mM} \mathrm{KCl,} 0.2 \mathrm{mM}$ PMSF, and $0.5 \mathrm{mM}$ dithiothreitol), vortexed for $10 \mathrm{sec}$, and incubated on ice for $15 \mathrm{~min}$. The packed cells were resuspended in ice-cold hypotonic lysis buffer in the presence of $50 \mu 1$ of $10 \%$ Nonidet P-40, and incubated on ice for $25 \mathrm{~min}$. Next, the nuclear fraction was precipitated by centrifugation at $13,000 \mathrm{x}$ g for $1 \mathrm{~min}$ at $4^{\circ} \mathrm{C}$, and the supernatants (cytosol extracts) were collected and stored at $-80^{\circ} \mathrm{C}$. The pelleted nuclei were resuspended in 50-100 $\mu 1$ of low salt extraction buffer (20 mM HEPES, pH 7.9, $1.5 \mathrm{mM} \mathrm{MgCl}, 25 \%$ glycerol, $20 \mathrm{mM} \mathrm{KCl}, 0.2 \mathrm{mM}$ EDTA, $0.2 \mathrm{mM}$ PMSF, and $0.5 \mathrm{mM}$ dithiothreitol), added to an equal volume of high salt extraction buffer (20 mM HEPES, pH 7.9, $1.5 \mathrm{mM} \mathrm{MgCl}_{2}, 25 \%$ glycerol, $80 \mathrm{mM} \mathrm{KCl}, 0.2 \mathrm{mM}$ EDTA, $0.2 \mathrm{mM}$ PMSF, and $0.5 \mathrm{mM}$ dithiothreitol) in a drop-wise fashion, and incubated under continuous shaking at $4^{\circ} \mathrm{C}$ for $45 \mathrm{~min}$. The sample was centrifuged for $20 \mathrm{~min}$ at $12,000 \mathrm{x} \mathrm{g}$. Aliquots of the nuclear extracts were stored at $-80^{\circ} \mathrm{C}$, and the protein concentration was determined.

Electrophoretic mobility shift assay (EMSA). The activation of NF- $\mathrm{kB}$ was assayed by a gel mobility shift assay using nuclear extracts from control and treated cells. An oligonucleotide containing the $\kappa$-chain binding site $\left(\kappa \mathrm{B}, 5^{\prime}-\mathrm{CCGG}\right.$ TTAACAGAGGGGGCTTTCCGAG-3') was synthesized and used as a probe for the gel retardation assay. The two complementary strands were annealed and labeled with $\left[\alpha^{-32} \mathrm{P}\right]-$ dCTP. Labeled oligonucleotides $(10,000 \mathrm{cpm}), 10 \mu \mathrm{g}$ of nuclear extracts and binding buffer $(10 \mathrm{mM}$ Tris-HCl, $\mathrm{pH} 7.6$, $500 \mathrm{mM} \mathrm{KCl}, 10 \mathrm{mM}$ EDTA, 50\% glycerol, $100 \mathrm{ng}$ poly(dI$\mathrm{dC}), 1 \mathrm{mM}$ dithiothreitol) were incubated for $30 \mathrm{~min}$ at room temperature in a final volume of $20 \mu \mathrm{l}$. Next, the reaction mixtures were analyzed by electrophoresis on $4 \%$ polyacrylamide gels in $0.5 \mathrm{X}$ Tris-borate buffer, and the gels were dried and examined by autoradiography.

Isolation of islets and insulin secretion assay. Pancreatic islets were isolated from male Sprague-Dawley rats using the collagenase digestion method, as described previously (17). Briefly, after treatment with cytokines for $24 \mathrm{~h}$, the islets were washed three times in Krebs-Ringer bicarbonate buffer (25 mM HEPES, $115 \mathrm{mM} \mathrm{NaCl}, 24 \mathrm{mM} \mathrm{NaHCO}, 5 \mathrm{mM}$ $\mathrm{KCl}, 1 \mathrm{mM} \mathrm{MgCl}$, $2.5 \mathrm{mM} \mathrm{CaCl}_{2}$, and $0.1 \%$ bovine serum albumin, pH 7.4) containing $3 \mathrm{mM} \mathrm{D-glucose,} \mathrm{and} \mathrm{insulin}$ secretion was then measured by static incubation of the islets for $30 \mathrm{~min}$ in the presence of either 5.5 or $20 \mathrm{mM} \mathrm{D}$-glucose. The insulin content of the medium was then determined by ELISA (Linco Research, St. Charles, MO).

Type 1 diabetes induction. Specific pathogen-free male ICR mice were purchased from Orientbio Inc. (Seoungnam, Korea) and housed at our animal facility for one week prior to use.
All mice used were 5-6-weeks old and were kept under specific pathogen-free conditions with free access to a standard commercial diet. To induce diabetes, mice were injected with $100 \mathrm{mg}$ of STZ/kg of body weight dissolved in $0.1 \mathrm{M}$ sodium citrate buffer ( $\mathrm{pH} 4.0$ ) via a tail vein. All injections of STZ were administered within 5 min of the treatment being prepared. Mice were administered $250 \mathrm{mg} / \mathrm{kg}$ RCE orally daily for three days before being administered the STZ injections. To determine the effects of RCE, mice were divided into the following groups; i) the non-treated control group, ii) the STZ group, iii) the RCE group, and 4) the RCE + STZ group ( $\mathrm{n}=5$, each group). The day on which the first STZ injection was administered is defined as day 1. Control group animals were administered citrate buffer alone. At day 5, the mice were sacrificed by decapitation without anesthesia and trunk blood was collected in prechilled tubes containing $1 \mathrm{mg} / \mathrm{ml}$ of EDTA for insulin and glucose determinations. The plasma glucose concentration was assayed by the glucose oxidase method (Sigma, St. Louis, MO), and the plasma insulin concentration was measured using an ELISA kit. All experimental procedures were approved by the Institutional Animal Care and Use Committee at Chonbuk National University.

Immunohistochemistry. For immunohistochemical staining, the Dako Envision system (Dako, Carpinteria, CA), which used dextran polymers conjugated with horseradish peroxidase, was employed to avoid any endogenous biotin contamination. Briefly, the pancreases were removed and immediately placed in fixative (10\% formalin solution in 0.1 M PBS). Histologic sections $4-\mu \mathrm{m}$ thick were cut from the formalin-fixed paraffinembedded tissue blocks. After deparaffinization, the tissue sections were treated using a microwave antigen retrieval procedure in $10 \mathrm{mM}$ sodium citrate buffer. The sections were blocked with endogenous peroxidase, after which they were incubated with Protein Block Serum-Free (Dako) to block non-specific staining. Next, the sections were incubated with anti-insulin antibody (Santa Cruz Biochemicals), and the peroxidase activity was detected using the enzyme substrate 3-amino-9-ethyl carbazole.

Statistical analysis. Statistical analyses of the data were performed using ANOVA and Duncan's test. Differences with a $\mathrm{p}<0.05$ were considered statistically significant.

\section{Results}

Prevention of cytokine-induced viability reduction by RCE. Based on the results of a previous study (18), a cytokine mix consisting of IL-1ß $(5 \mathrm{ng} / \mathrm{ml})$ and IFN- $\gamma(100 \mathrm{U} / \mathrm{ml})$ was employed throughout the current study to maintain a stable toxic effectiveness. RIN cells from a rat pancreatic $\beta$-cell line were cultured to near confluence and then pretreated with or without RCE for $3 \mathrm{~h}$. These cells were exposed to cytokines for $24 \mathrm{~h}$ or $48 \mathrm{~h}$ and their viability was assessed by an MTT assay. Treatment with cytokines significantly reduced the cell viability to $46.4 \pm 0.7 \%$ and $19.6 \pm 0.4 \%$ of that of the control at 24 and $48 \mathrm{~h}$, respectively (Fig. 1, upper panel). Conversely, RCE increased the viability of cytokine-treated RIN cells in a concentration-dependent manner. The protective effect of RCE on cytokine-induced viability change was 

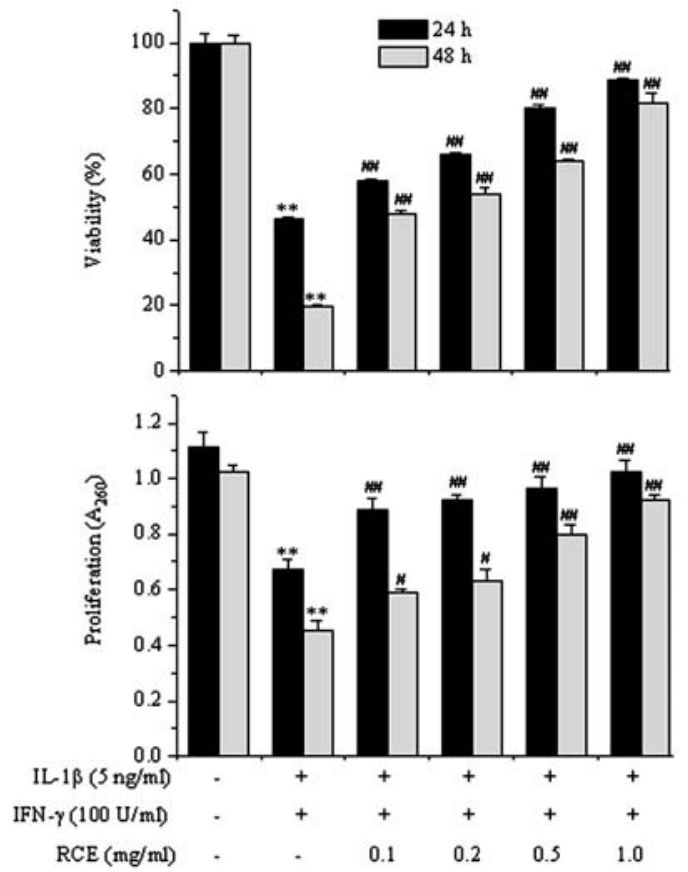

Figure 1. RCE prevents cytokine-induced cell death in RIN cells. RIN cells were pretreated with the indicated concentrations of RCE for $3 \mathrm{~h}$, after which IL-1ß $(5 \mathrm{ng} / \mathrm{ml})$ and IFN- $\gamma(100 \mathrm{U} / \mathrm{ml})$ were added for $24 \mathrm{~h}$ or $48 \mathrm{~h}$. The cell viability and cell proliferative potential were then determined by an MTT (upper panel) and BrdU incorporation assay (lower panel), respectively. Each value is the mean \pm SEM of three independent experiments. ${ }^{* *} \mathrm{p}<0.01$ vs. untreated control; ${ }^{\#} \mathrm{p}<0.05 ;{ }^{\# \#} \mathrm{p}<0.01$ vs. IL-1ß+IFN- $\gamma$.

further confirmed by evaluating BrdU incorporation in RIN cells. BrdU is a thymidine analog that is incorporated into proliferating cells during DNA synthesis; thus it reflects the proliferative potential of the cells. Cytokines reduced the level of BrdU incorporation to $58.2 \pm 0.3$ and $44.5 \pm 0.4 \%$ of the control levels at 24 and $48 \mathrm{~h}$, respectively, indicating that cytokines reduced proliferation. Similar to the results of the MTT assay, RCE was found to prevent the cytokine-mediated decrease in cell proliferation potential in a concentrationdependent manner (Fig. 1, lower panel). It should be noted that treatment with the tested concentrations of RCE alone did not affect the viability of RIN cells (data not shown).

Effect of RCE on IL-1 $\beta$ and IFN- $\gamma$-induced NO production and iNOS expression. It has been reported that cytokinemediated destruction of $B$ cells is caused by an increase of NO production $(5,6)$. Incubation of RIN cells with cytokines for $24 \mathrm{~h}$ resulted in significant production of nitrite (a stable oxidized product of NO) by these cells (Fig. 2); however, the presence of RCE diminished the cytokine-mediated NO production, which was well correlated with their increased viability. To examine whether RCE inhibits NO production via suppression of iNOS gene expression, the changes in iNOS mRNA and protein expression were investigated by real-time PCR and Western blotting, respectively. The iNOS mRNA and protein expressions were markedly increased in cells treated with cytokines, whereas cells pretreated with RCE showed suppression of the cytokine-induced iNOS expression at both the mRNA and protein levels (Fig. 2).

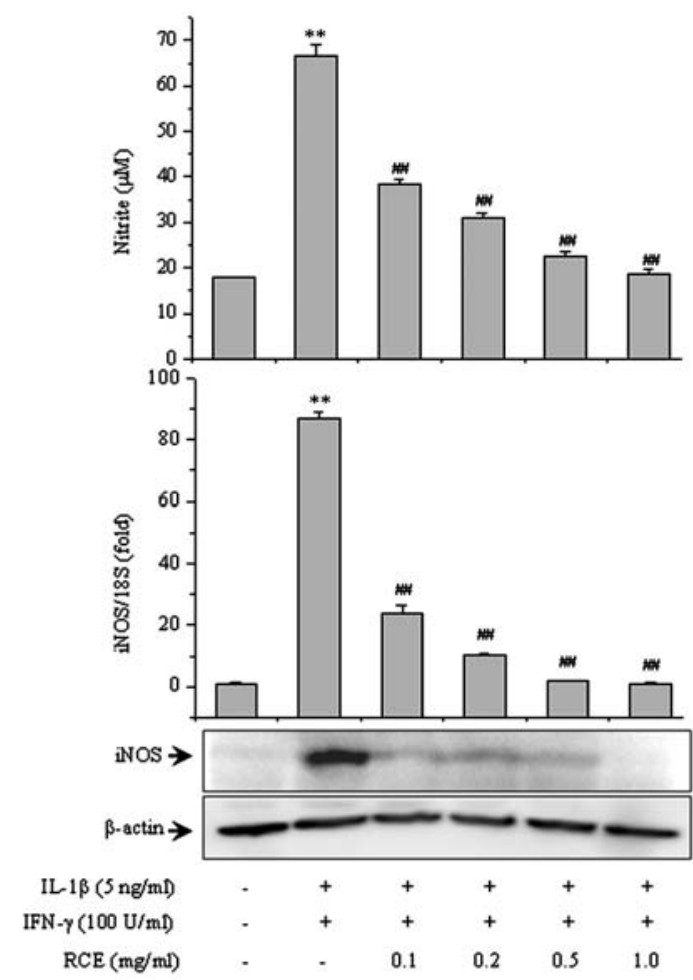

Figure 2. RCE inhibits cytokine-induced NO production and iNOS expression in RIN cells. RIN cells were pretreated with the indicated concentrations of RCE for $3 \mathrm{~h}$, after which IL-1ß and IFN- $\gamma$ were added. Following $24 \mathrm{~h}$ of incubation, the levels of nitrite production and iNOS mRNA and protein expression were determined. The results of triplicate samples are expressed as the mean \pm SEM. ${ }^{* *} \mathrm{p}<0.01$ vs. untreated control; ${ }^{\# \#} \mathrm{p}<0.01$ vs. IL- $1 \beta+\mathrm{IFN}-\gamma$.

Effect of RCE on IL-1 $\beta$ and IFN- $\gamma$-induced $N F-\kappa B$ activation. $\mathrm{NF}-\kappa \mathrm{B}$ has been implicated in the transcriptional regulation of cytokine-induced iNOS expression. Therefore, we studied the effect of RCE on cytokine-stimulated activation of the NF- $\mathrm{KB}$ pathway in RIN cells. Cytokine-treated RIN cells showed increased binding activity toward an NF- $\kappa \mathrm{B}$ consensus sequence (Fig. 3A), as well as increased p65 subunit levels in their nuclei and $\mathrm{I} \kappa \mathrm{B} \alpha$ degradation in their cytosol (Fig. 3B) when compared to unstimulated cells. Additionally, cytokineinduced NF- $\mathrm{\kappa B}$ activation was markedly suppressed by pretreatment with RCE, which suggests that RCE inhibits iNOS expression through inhibition of $N F-\kappa B$ activation. The specificity of the DNA-protein interaction for $\mathrm{NF}-\kappa \mathrm{B}$ was demonstrated by performing competition assays using a 50-fold excess of unlabeled oligonucleotide (Fig. 3A, lane 7).

Suppression of the cytokine-induced $N F-\kappa B$ pathway and preservation of glucose-stimulated insulin secretion (GSIS) by $R C E$ in rat islets. We further assayed the preventive effects of RCE using rat pancreatic islets isolated from the male Sprague-Dawley rat to support the physiological importance of the results observed in the cell line studies. Incubation of rat islets for $24 \mathrm{~h}$ with cytokines resulted in a 2.8 -fold increase in NO production (Fig. 4A). Additionally, real-time PCR and Western blotting revealed that iNOS mRNA and protein levels were markedly increased in response to treatment with cytokines (Fig. 4A). In addition, similar to the results 
A
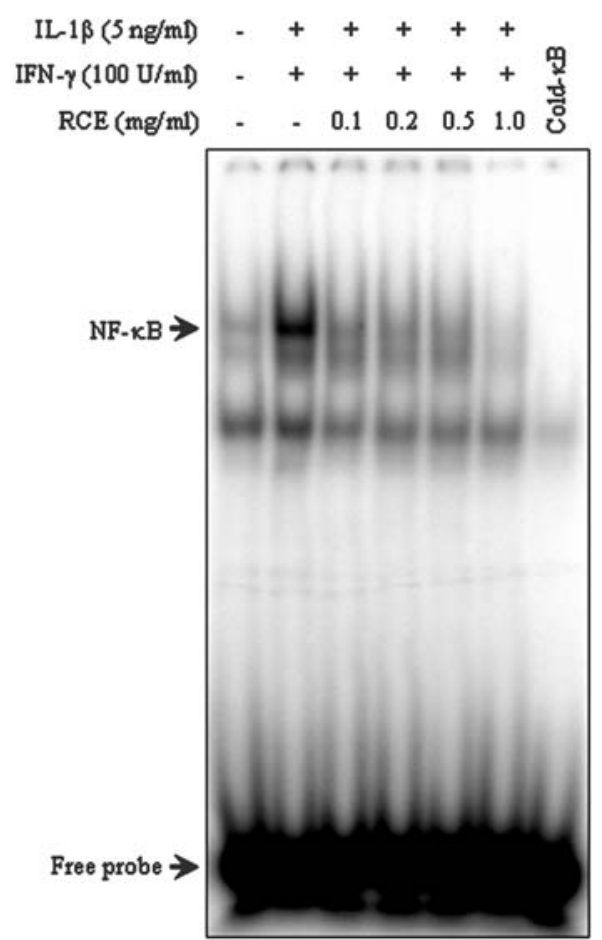

B

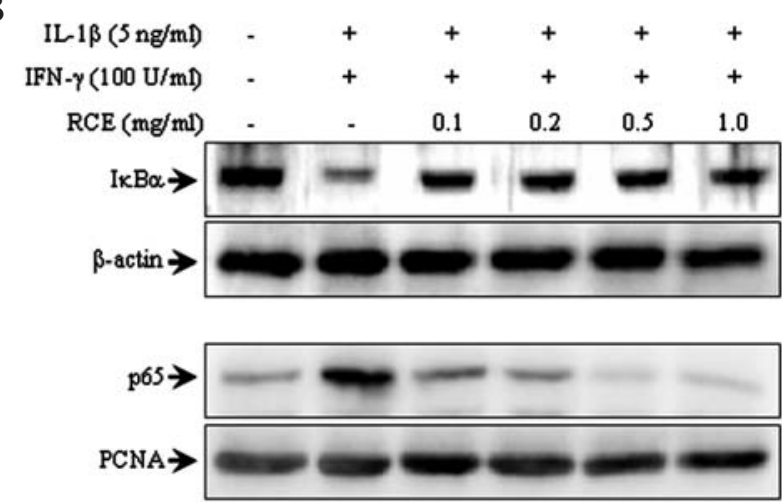

Figure 3. RCE inhibits cytokine-induced DNA binding of NF- $\kappa \mathrm{B}$, translocation of $\mathrm{p} 65$ to the nucleus, and IкB $\alpha$ degradation in RIN cells. RIN cells were pretreated with the indicated concentrations of RCE for $3 \mathrm{~h}$, after which the cytokines were added. Following $30 \mathrm{~min}$ of incubation, DNA binding of NF- $\kappa \mathrm{B}$ was analyzed by EMSA (A) and the translocation of p65 to the nucleus and $\mathrm{I} \kappa \mathrm{B} \alpha$ degradation in the cytoplasm (B) were determined by Western blotting. B-actin and PCNA were used as loading controls for cytosolic and nuclear proteins, respectively.

obtained using the RIN cells, pretreatment of the islets with RCE abolished the effects of cytokines and reduced the NO production and iNOS expression to the control levels. Treatment with cytokines also increased the NF- $\kappa$ B DNA binding activity in islets (Fig. 4B); however, pretreatment of the islets with RCE completely abolished the effects of cytokines. To add functional data, we determined whether RCE could protect against cytokine-induced impairment of GSIS. After $24 \mathrm{~h}$ of exposure to the cytokines, insulin secretion was assayed in response to $20 \mathrm{mM}$ glucose. Control islets secreted insulin at a concentration of $20.3 \pm 1.1 \mathrm{ng} / \mathrm{ml}$, whereas insulin secretion from cytokine-treated islets decreased significantly to $10.9 \pm 0.9 \mathrm{ng} / \mathrm{ml}(\mathrm{p}<0.01)$ (Fig. 4C). However, pretreatment with RCE blocked the effect of the cytokines and restored the islet cell insulin secretion to levels
A

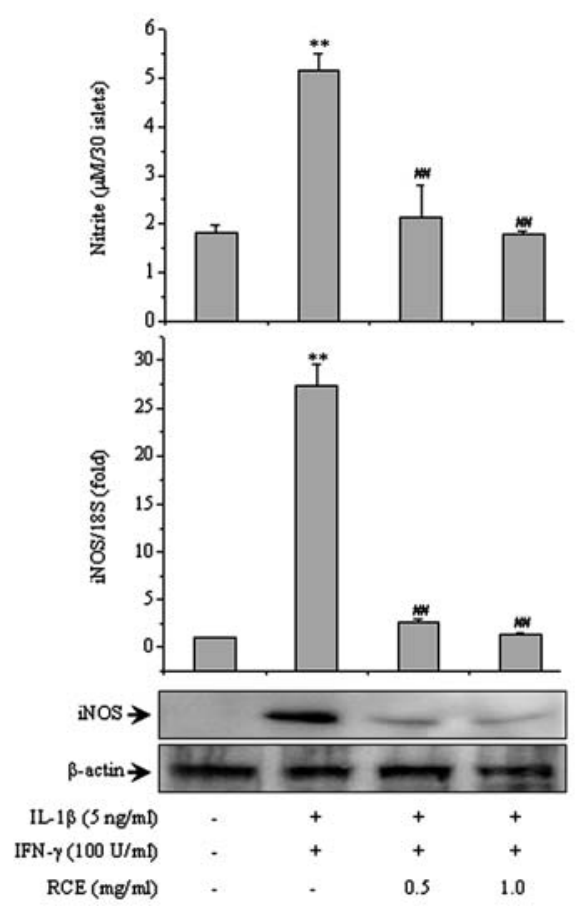

B

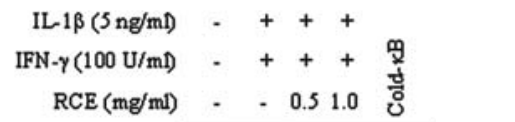

C
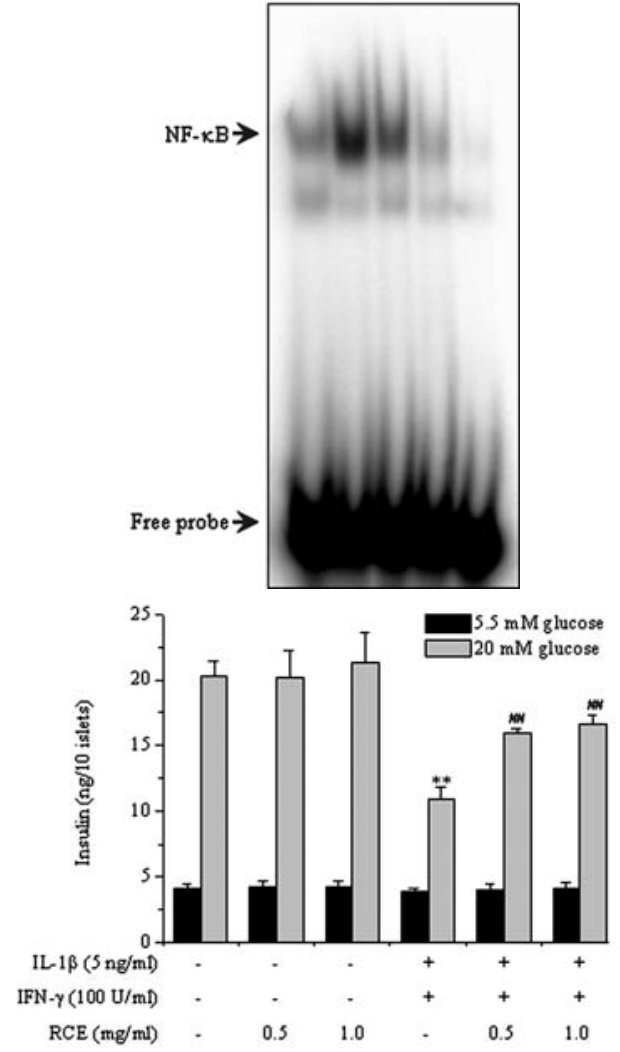

Figure 4. RCE inhibits cytokine-induced activation of the NF- $\mathrm{kB}$ pathway and restores glucose-stimulated insulin secretion in rat islets. Rat islets were treated with cytokines with or without a 3-h pretreatment with the indicated concentrations of RCE. Nitrite production (30 islets) and iNOS mRNA (80 islets) and protein expressions (30 islets) (A) were determined $24 \mathrm{~h}$ later, and the DNA binding of NF-кB (100 islets) (B) was then determined $30 \mathrm{~min}$ later. Rat islets $(10$ islets $/ 500 \mu 1)$ were treated with cytokines with or without a 3-h pretreatment with the indicated concentrations of RCE. Following $24 \mathrm{~h}$ of incubation, the glucose-stimulated insulin secretion was quantified $(\mathrm{C})$. The results of triplicate samples are expressed as the mean \pm SEM. ${ }^{* *} \mathrm{p}<0.01$ vs. untreated control; ${ }^{\#} \mathrm{p}<0.01 \mathrm{vs}$. IL- $1 \beta+\mathrm{IFN}-\gamma$. 
A

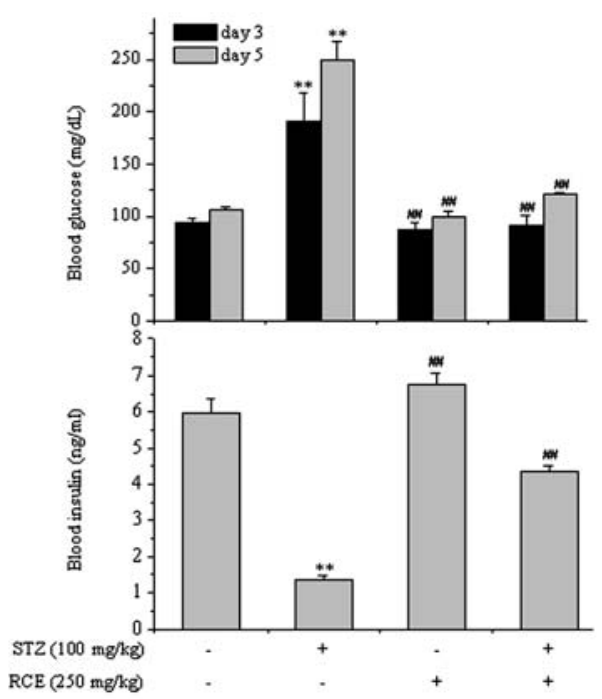

C
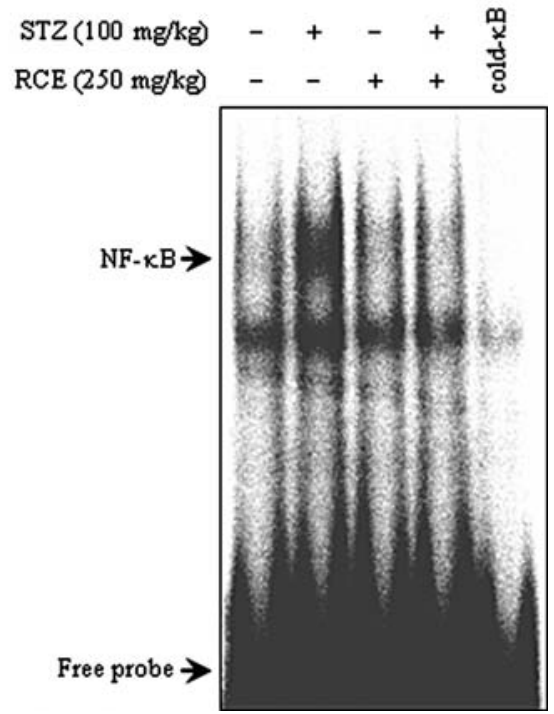

B

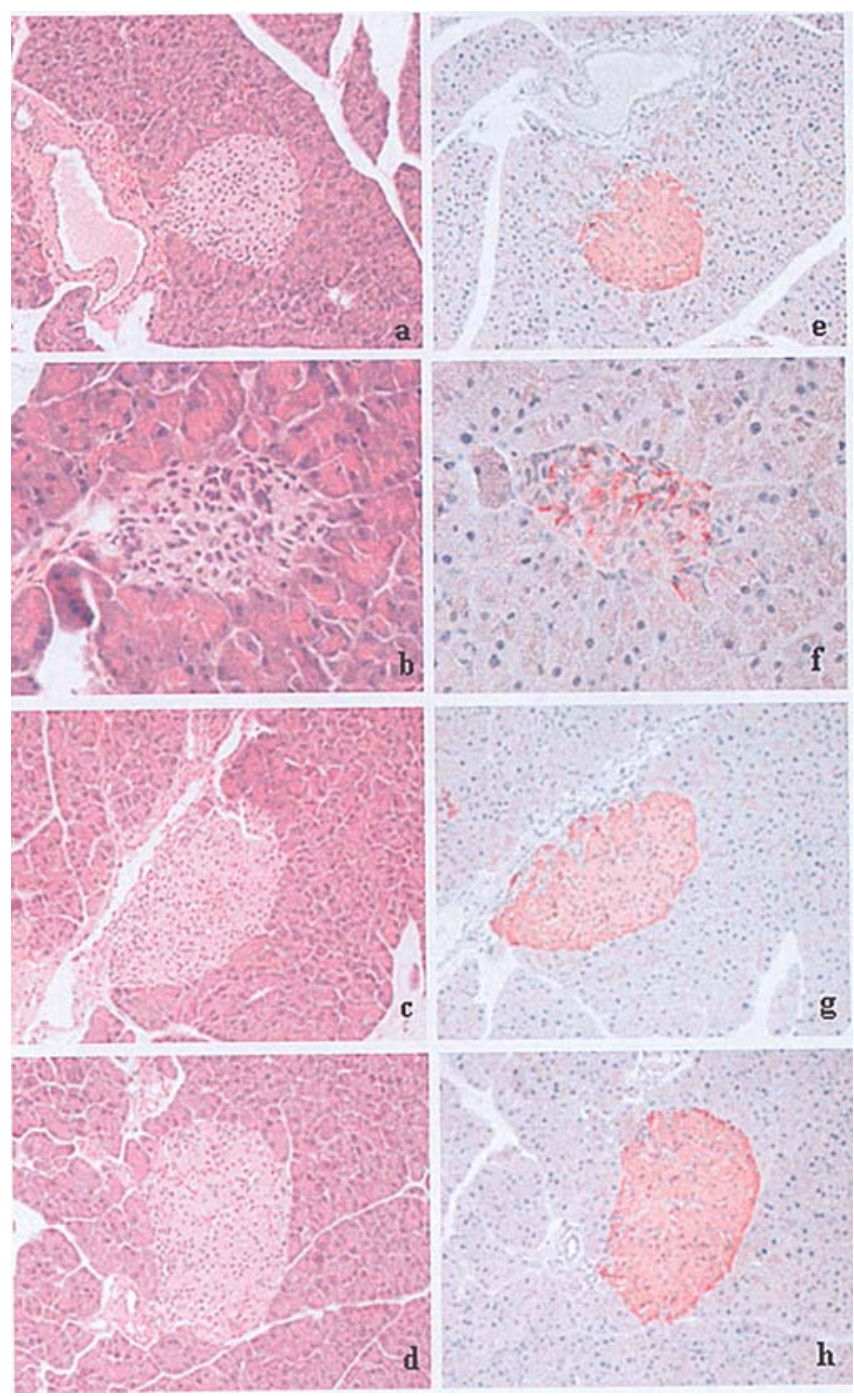

Figure 5. RCE protects islets from STZ-induced destruction. ICR mice were administered RCE via oral administration at a daily dose of 250 mg/kg for three days, and then intravenously injected with STZ $(100 \mathrm{mg} / \mathrm{kg})$. The levels of fasting glucose and insulin were then determined (A). Pancreases were obtained from normal controls (a and e), STZ-injected mice (b and f), RCE-treated mice (c and g), and RCE and STZ-injected mice ( $\mathrm{d}$ and h) (B). The cellular morphologies of the islets and of the adjoining exocrine regions were counterstained with $\mathrm{H} \& \mathrm{E}$ (a-d). Islets were labeled for insulin antibody and peroxidase-labeled anti-rabbit IgG and examined by microscopy (e-h). Nuclear extracts from pancreatic tissues were prepared 30 min after STZ injection and DNA binding of NF- $\mathrm{kB}$ was analyzed by EMSA (C). ${ }^{* *} \mathrm{p}<0.01 \mathrm{vs}$. untreated control; ${ }^{\# \#} \mathrm{p}<0.01$ vs. STZ-injected group.

similar to that of the control. RCE itself did not affect the insulin secreting response to glucose.

Effect of RCE on the STZ-induced type 1 diabetes model. To assess the potential of RCE to protect against STZ-mediated type 1 diabetes, ICR mice were injected with a single high dose of STZ with or without a previous injection of RCE. The results revealed a striking resistance to the development of diabetes following STZ injection in RCE-pretreated mice when compared with untreated controls. As expected, mice that received STZ became hyperglycemic and hypoinsulinemic at $72 \mathrm{~h}$. The blood glucose and insulin levels of these mice at day 5 were $249.4 \pm 17.7 \mathrm{mg} \%$ and $1.4 \pm 50.1 \mathrm{ng} / \mathrm{ml}$, respectively, which is well within the acceptable diabetic range. Conversely, mice that were pretreated with RCE and then treated with STZ showed normal blood glucose and insulin values (Fig. 5A). Next, pancreatic islets were histologically examined. Pancreatic tissues were obtained 5 days after STZ administration with or without RCE pretreatment and then subjected to H-E staining and immunohistochemistry. In STZ-injected mice, the most consistent findings in pancreatic sections stained with $\mathrm{H} \& \mathrm{E}$ were degenerative and necrotic changes in $\beta$ cells (Fig. 5B, b). In addition, immunohistochemical staining showed weak insulin-reactivity (Fig. 5B, f). However, H\&E staining and immunohistochemistry revealed that diabetic mice pretreated with RCE had near-normal islets (a well marginated and round shape with strong insulin positivity in islet $B$ cells) (Fig. 5B, d and h). Finally, potential mechanisms involved in the beneficial effect of RCE on STZ toxicity were investigated. As shown in Fig. 5C, STZ treatment rapidly increased the level of NF-кB DNA binding (Fig. 5C) in the pancreas, whereas pretreatment with RCE completely inhibited STZ-induced $\mathrm{NF}-\kappa \mathrm{B}$ activation, suggesting that suppression of the NF-кB 
pathway may be a potential mechanism involved in the antidiabetic effect of RCE on STZ toxicity.

\section{Discussion}

The results of this study demonstrated that RCE exerts antidiabetic effects on pancreatic $\beta$ cells that have been challenged with cytokines or STZ. RCE was found to prevent both forms of cytokine-induced $\beta$-cell death in RIN cells and primary rat islets. Furthermore, the results of this study demonstrated that RCE had protective effects against the development of type 1 diabetes induced by STZ. Additionally, this study demonstrated that the preventive actions of RCE on cytokines and STZ toxicity were associated with suppression of the $\mathrm{NF}-\kappa \mathrm{B}$ pathway.

In pancreatic $B$ cells, inhibition of iNOS has been shown to prevent apoptosis, which indicates that increased NO production due to $\mathrm{NF}-\kappa \mathrm{B}$ activation is an important signal in cytokine-induced apoptosis (19-21). Therefore, the process leading to the production of NO in response to treatment with cytokines and suppression of this process by RCE were investigated in this study. When analyzing the NF- $\mathrm{B}$ binding activity in cytokine-treated RIN cells, a clear increase in the specific band intensity was observed, whereas attenuation was observed in cells that had been pretreated with RCE. In addition, treatment of RIN cells with RCE prior to stimulation by cytokines resulted in inhibition of $\mathrm{I} \kappa \mathrm{B} \alpha$ degradation and parallel translocation of p65 into the nucleus, which suggests that RCE acts upstream from IкB $\alpha$ degradation. Although the upstream signaling pathway leading to I $\mathrm{K} \mathrm{B} \alpha$ restoration by RCE is not clear, our results are in agreement with those of a recent study that found Ad-IкB $\alpha$ (S32A, S36A), a non-degradable IкB $\alpha$ mutant, to be effective at preventing cytokine toxicity (13). Even though most of the experiments described here were conducted on RIN cells, the observed phenomena are not unique to this type of cell because similar protection against cytokines toxicity has also been observed in isolated rat islets. Therefore, we believe that the phenomenon described in this article also applies to other insulinoma cells and pancreatic islets.

$\mathrm{NF}-\kappa \mathrm{B}$ governs both proinflammatory and antiapoptotic responses according to the modes of insults in $\beta$-cells. For example, NF- $\mathrm{NB}$ regulates the expression of multiple proinflammatory genes that contribute to islet destruction such as Fas, iNOS and cyclooxygenase- $2(6,13,22)$. In addition, the promoters of other proinflammatory genes induced in $\beta$ cells, including chemokines and adhesion molecules, also possess

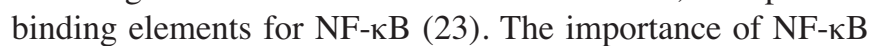
in $\beta$-cell damage is underscored by the fact that inhibition of $\mathrm{NF}-\kappa \mathrm{B}$ activation or translocation prevents IL-1ß and IFN- $\gamma$ induced $B$-cell dysfunction and death both in vitro and in vivo (11-13). Conversely, it is also known that NF-кB has a defensive and protective role (13). For example, NF-кB limited the tissue damage in a cerulein-induced acute pancreatitis model, whereas blocking NF- $\mathrm{KB}$ activation had an adverse effect by increasing apoptosis, thereby causing more tissue damage (24). NF- $\mathrm{\kappa B}$ regulates apoptosis by controlling the expression of multiple anti-apoptotic genes including the inhibitor of apoptosis protein (IAP) and A20 $(25,26)$. Blockade of NF- $\kappa \mathrm{B}$ via the use of an $\mathrm{I} \kappa \mathrm{B} \alpha$ super-repressor also sensitized $\beta$ cells to TNF- $\alpha$-mediated apoptosis (27). Therefore, it remains unclear whether NF- $\mathrm{KB}$ activation in the pancreas is protective or detrimental.

We used the STZ-induced diabetes model to study the role of NF-кB in vivo. RCE completely blocked the type 1 diabetes that develops in response to STZ, and this was paralleled by a preserved $\beta$-cell mass. STZ destroys $\beta$ cells and causes diabetes by inducing DNA alkylation (28). In addition, the diabetic effects of STZ may also be a result of the NO release $(9,10)$. It has been reported that systemic p50 or c-RelA null mice are resistant to STZ $(29,30)$, which supports the importance of the NF-кB pathway in STZinduced diabetes development. Following injection with STZ, pancreatic islets showed obvious B-cell damage with degenerative and necrotic changes to $\beta$ cells and reduced staining for insulin. We also observed an increase in the activation of NF- $\kappa \mathrm{B}$ in the pancreas of STZ-treated mice, and the ability of RCE to protect against the development of type 1 diabetes was correlated with its ability to inhibit NF- $\mathrm{KB}$ activation. Therefore, it is possible that the RCE-induced suppression of $\mathrm{NF}-\mathrm{\kappa B}$ activation is crucial for its protective effects to occur.

In conclusion, we showed herein that RCE protects $\beta$ cells against cytokines or STZ, thereby maintaining the insulin secretion capacity of islets. Recent success in islet transplantation has focussed attention on cell-based insulin replacement strategies for the treatment of type 1 diabetes. However, limited tissue supply and concerns regarding the life-long administration of immunosuppressive agents may limit the applicability of this approach (31). The beneficial effect of RCE on $\beta$ cells may lead to therapeutic and preventive approaches aimed at enhancing the survival of $\beta$ cells, thereby reducing or delaying cytokine-mediated $B$-cell destruction.

\section{Acknowledgements}

This work was supported by the Regional Research Centers Program of the Korean Ministry of Education \& Human Resources Development through the Center for Healthcare Technology Development and by a grant from the Ministry of Science \& Technology (MoST)/Korea Science \& Engineering Foundation (KOSEF) through the Vestibulocochlear Research Center (VCRC) at Wonkwang University (R13-2002-0550000-0).

\section{References}

1. Nossal GJ, Herold KC and Goodnow CC: Autoimmune tolerance and type 1 (insulin-dependent) diabetes mellitus. Diabetologia 35 (Suppl 2): S49-S59, 1992.

2. Papaccio G: Insulitis and islet microvasculature in type 1 diabetes. Histol Histopathol 8: 751-759, 1993.

3. Scherbaum WA: Etiology and pathogenesis of type 1 diabetes. Horm Metab Res (Suppl) 26: 111-116, 1992.

4. Hohmeier HE, Tran VV, Chen G, Gasa R and Newgard CB: Inflammatory mechanisms in diabetes: lessons from the $\beta$ cell. Int J Obes Relat Metab Disord 27 (Suppl 3): S12-S16, 2003.

5. Arnush M, Heitmeier MR, Scarim AL, Marino MH, Manning PT and Corbett JA: IL-1 produced and released endogenously within human islets inhibits B cell function. J Clin Invest 102: 516-526, 1998.

6. Cetkovic-Cvrlje M and Eizirik DL: TNF- $\alpha$ and IFN- $\gamma$ potentiate the deleterious effects of IL- $1 ß$ on mouse pancreatic islets mainly via generation of nitric oxide. Cytokine 6: 399-406, 1994. 
7. Kaneto H, Fujii J, Seo HG, Suzuki K, Matsuoka T, Nakamura M, Tatsumi H, Yamasaki Y, Kamada T and Taniguchi N: Apoptotic cell death triggered by nitric oxide in pancreatic $\beta$-cells. Diabetes 44: 733-738, 1995

8. Stadler J, Billiar TR, Curran RD, Stuehr DJ, Ochoa JB and Simmons RL: Effect of exogenous and endogenous nitric oxide on mitochondrial respiration of rat hepatocytes. Am J Physiol 260: C910-C916, 1991.

9. Carlsson PO, Flodstrom M and Sandler S: Islet blood flow in multiple low dose streptozotocin-treated wild-type and inducible nitric oxide synthase-deficient mice. Endocrinology 141: 2752-2757, 2000.

10. Tsuji A and Sakurai H: Generation of nitric oxide from streptozotocin (STZ) in the presence of copper(II) plus ascorbate: implication for the development of STZ-induced diabetes. Biochem Biophys Res Commun 245: 11-16, 1998.

11. Giannoukakis N, Rudert WA, Trucco M and Robbins PD: Protection of human islets from the effects of interleukin-1ß by adenoviral gene transfer of an IкB repressor. J Biol Chem 275: 36509-36513, 2000.

12. Heimberg H, Heremans Y, Jobin C, Leemans R, Cardozo AK, Darville M and Eizirik DL: Inhibition of cytokine-induced NF- $\mathrm{kB}$ activation by adenovirus-mediated expression of a NF- $\mathrm{\kappa B}$ superrepressor prevents $B$-cell apoptosis. Diabetes 50: 2219-2224, 2001.

13. Kim EK, Kwon KB, Koo BS, Han MJ, Song MY, Song EK, Han MK, Park JW, Ryu DG and Park BH: Activation of peroxisome proliferator-activated receptor- $\gamma$ protects pancreatic B-cells from cytokine-induced cytotoxicity via NF- $\mathrm{kB}$ pathway. Int J Biochem Cell Biol 39: 1260-1275, 2007.

14. Baeuerle PA and Henkel T: Function and activation of NF-кB in the immune system. Annu Rev Immunol 12: 141-179, 1994.

15. Baldwin AS Jr: The NF-кB and IкB proteins: new discoveries and insights. Annu Rev Immunol 14: 649-683, 1996.

16. Moncada S, Palmer RM and Higgs EA: Nitric oxide: physiology, pathophysiology, and pharmacology. Pharmacol Rev 43: 109-142, 1991.

17. Park BH, Rho HW, Park JW, Cho CG, Kim JS, Chung HT and Kim HR: Protective mechanism of glucose against alloxaninduced pancreatic $B$-cell damage. Biochem Biophys Res Commun 210: 1-6, 1995.

18. Kim EK, Kwon KB, Han MJ, Song MY, Lee JH, Lv N, Ka SO, Yeom SR, Kwon YD, Ryu DG, Kim KS, Park JW, Park R and Park BH: Coptidis rhizoma extract protects against cytokineinduced death of pancreatic B-cells through suppression of NF-кB activation. Exp Mol Med 39: 149-159, 2007.
19. Cnop M, Welsh N, Jonas JC, Jorns A, Lenzen S and Eizirik DL: Mechanisms of pancreatic $\beta$-cell death in type 1 and type 2 diabetes: many differences, few similarities. Diabetes 54 (Suppl 2): S97-S107, 2005.

20. Mandrup-Poulsen T: $B$ cell death and protection. Ann NY Acad Sci 1005: 32-42, 2003.

21. McDaniel ML, Kwon G, Hill JR, Marshall CA and Corbett JA: Cytokines and nitric oxide in islet inflammation and diabetes Proc Soc Exp Biol Med 211: 24-32, 1996.

22. Darville MI and Eizirik DL: Cytokine induction of Fas gene expression in insulin-producing cells requires the transcription factors NF-кB and C/EBP. Diabetes 50: 1741-1748, 2001.

23. May MJ and Ghosh S: Signal transduction through NF-кB. Immunol Today 19: 80-88, 1998

24. Steinle AU, Weidenbach H, Wagner M, Adler G and Schmid RM: $\mathrm{NF}-\mathrm{\kappa B} / \mathrm{Rel}$ activation in cerulein pancreatitis. Gastroenterology 116: 420-430, 1999 .

25. Karin M and Lin A: NF- $\mathrm{KB}$ at the crossroads of life and death. Nat Immunol 3: 221-227, 2002.

26. Liuwantara D, Elliot M, Smith MW, Yam AO, Walters SN, Marino E, McShea A and Grey ST: Nuclear factor- $\kappa B$ regulates B-cell death: a critical role for A20 in B-cell protection. Diabetes 55: 2491-2501, 2006

27. Chang I, Kim S, Kim JY, Cho N, Kim YH, Kim HS, Lee MK, Kim KW and Lee MS: Nuclear factor- $\mathrm{KB}$ protects pancreatic $\beta$-cells from tumor necrosis factor- $\alpha$-mediated apoptosis. Diabetes 52: 1169-1175, 2003.

28. Elsner M, Guldbakke B, Tiedge M, Munday R and Lenzen S: Relative importance of transport and alkylation for pancreatic ß-cell toxicity of streptozotocin. Diabetologia 43: 1528-1533, 2000 .

29. Lamhamedi-Cherradi SE, Zheng S, Hilliard BA, Xu L, Sun J, Alsheadat S, Liou HC and Chen YH: Transcriptional regulation of type I diabetes by NF-кB. J Immunol 171: 48864892, 2003

30. Mabley JG, Hasko G, Liaudet L, Soriano F, Southan GJ, Salzman AL and Szabo C: NFkB1 (p50)-deficient mice are not susceptible to multiple low-dose streptozotocin-induced diabetes. J Endocrinol 173: 457-464, 2002.

31. Buteau J, El-Assaad W, Rhodes CJ, Rosenberg L, Joly E and Prentki M: Glucagon-like peptide-1 prevents $\beta$ cell glucolipotoxicity. Diabetologia 47: 806-815, 2004. 